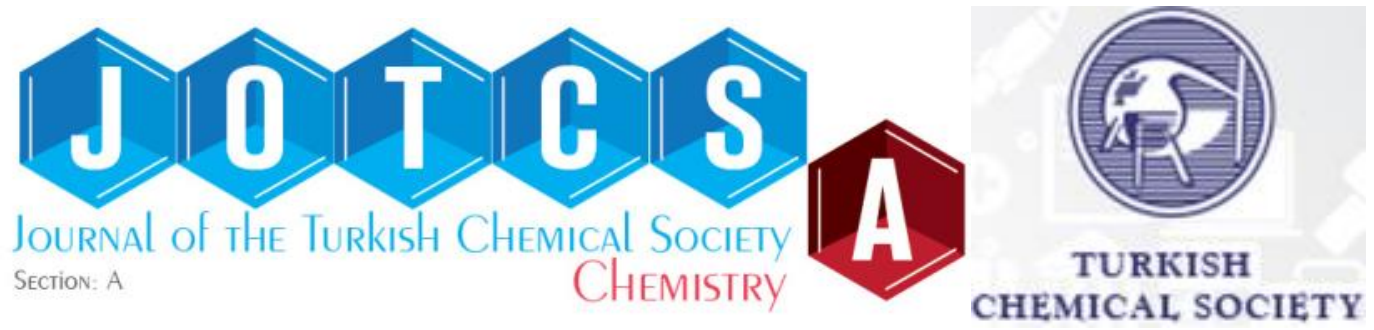

\title{
Synthesis of Stable Nano Calcite
}

\author{
Sevgi KILIC $\square$
}

Department of Chemical Engineering, Izmir Institute of Technology, Urla, Izmir, 35430-Turkey.

Abstract: Synthesis of calcium carbonate $\left(\mathrm{CaCO}_{3}\right)$ particles in the presence of a population of carbon dioxide $\left(\mathrm{CO}_{2}\right)$ bubbles was investigated in the calcium hydroxide $\left(\mathrm{Ca}(\mathrm{OH})_{2}\right)$ solution, which is a natural stabilizer for $\mathrm{CaCO}_{3}$. Possible chemical speciation reactions were presented for an inorganic synthesis of hollow nano$\mathrm{CaCO}_{3}$ particles. In the progress of $\mathrm{CaCO}_{3}$ synthesis, some of the particles started to dissolve at their edges and turned into hollow nano- $\mathrm{CaCO}_{3}$ particles. Some of the pores closed at the end of crystallization as a result of dissolution-recrystallization mechanism. Hollow nano- $\mathrm{CaCO}_{3}$ particles with sizes of about $300 \mathrm{~nm}$ were synthesized with a narrow size distribution. It was concluded that the hollow nano- $\mathrm{CaCO}_{3}$ particles could be advantageous due to lower weights and higher surface areas.

Keywords: Hollow particles, nanoparticles, $\mathrm{CaCO}_{3}$, stability, zeta potential, $\mathrm{CO}_{2}$ sequestration.

Submitted: December 26, 2017. Accepted: July 12, 2018.

Cite this: Kilic S. Synthesis of Stable Nano Calcite. JOTCSA. 2018;5(2):869-80.

DOI: http://dx.doi.org/10.18596/jotcsa.371374.

*Corresponding author. e-mail: sevgikilic@iyte.edu.tr; Ph.: +90(232)7506647; Fax: +90(232)7506645

\section{INTRODUCTION}

Calcium carbonate $\left(\mathrm{CaCO}_{3}\right)$ is one of the cheapest filling materials widely used in paper, cement, and paint industries to decrease the product's cost and to enhance the physical properties of the composite materials. The enhancement in the physical properties of the composite materials is more important when the particles are used in nano sizes (1). However, production of $\mathrm{CaCO}_{3}$ particles in nano sizes and at narrow size distribution is difficult and rare in the literature (24). Therefore, new methods need to be developed to produce monodispersed nano $\mathrm{CaCO}_{3}$ particles in large scale.

Calcium carbonate from nature was generally supplied to the industry after a series of crushing, grinding, and sieving processes called Ground Calcium Carbonate (GCC) (ㅁ). However, nano$\mathrm{CaCO}_{3}$ particles cannot be obtained in the GCC process. Furthermore, the produced micron to millimeter sized $\mathrm{CaCO}_{3}$ are not in desired quality, homogenous size distribution, and purity (므). Nano- $-\mathrm{CaCO}_{3}$ particles therefore need to be synthesized by recrystallization methods. There are basically two recrystallization methods for the $\mathrm{CaCO}_{3}$ synthesis. One is chemical method where sodium carbonate $\left(\mathrm{Na}_{2} \mathrm{CO}_{3}\right)$ and calcium chloride $\left(\mathrm{CaCl}_{2}\right)$ are used as reactants (6). For this case, other ions such as $\mathrm{Na}^{+}$and $\mathrm{Cl}^{-}$play an important role on crystallization and bigger particles are produced with sizes larger than $3 \mu \mathrm{m}$ (7). The other method is carbonization method and uses carbon dioxide $\left(\mathrm{CO}_{2}\right)$ and calcium hydroxide $\left(\mathrm{Ca}(\mathrm{OH})_{2}\right)$ as the reactants $(8-10)$. Nano size particles can be produced in carbonization method depending on concentration and temperature of the solution (11). There are different carbonation methods appeared in the literature to synthesize nano- $\mathrm{CaCO}_{3}$ particles. Examples are reactive crystallization processes (12-15), sono-chemical processes (16, 17), sol-gel processes (18), reverse-microemulsion processes $(19,20)$, and supercritical chemical processes $(16,21)$. In reactive crystallization processes, $\mathrm{Ca}(\mathrm{OH})_{2}-\mathrm{CO}_{2}-$ $\mathrm{H}_{2} \mathrm{O}$ multiphase system is used to produce $\mathrm{CaCO}_{3}$ nanoparticles. Temperature, concentration of reactants, stirring rates as well as mechanisms of $\mathrm{CO}_{2}$ transport to the gas-liquid interface were 
investigated as the process parameters to obtain nanocrystals (22). In sonochemical process, ultrasonic agitation was employed for a high conversion from $\mathrm{Ca}(\mathrm{OH})_{2}$ to precipitated $\mathrm{CaCO}_{3}$ particles. Crystallization usually takes place with the formation of a $\mathrm{CaCO}_{3}$ layer around the $\mathrm{Ca}(\mathrm{OH})_{2}$ particles causing a diffusion limitation for $\mathrm{Ca}^{2+}$ ions. These limitations could be overcome by the type of stirring and/or increasing the stirring rate. Smaller particles were obtained in short times (16). In sol-gel process, $\mathrm{CaCO}_{3}$ particles were synthesized by reacting $\mathrm{Ca}(\mathrm{OH})_{2}$ with $\mathrm{CO}_{2}$ in the presence of methanol. The resulting product was an aerogel. The aerogel was dried with supercritical carbon dioxide $\left({ }_{\mathrm{sc}} \mathrm{CO}_{2}\right)$ to produce $\mathrm{CaCO}_{3}$ aerogel. $\mathrm{CaCO}_{3}$ aerogel formation was a three-step process; primary $\mathrm{CaCO}_{3}$ nanoparticles formation (5-20 nm), secondary particles formation by growing primary particles (spherical or fiber-like) and aggregation to the $\mathrm{CaCO}_{3}$ gel (18). In reverse microemulsion system, $\mathrm{CO}_{2}$ dissolved in an organic phase and diffused into the reverse micelles containing $\mathrm{Ca}(\mathrm{OH})_{2}$, where $\mathrm{CaCO}_{3}$ particles produced at the superstation. The nucleation and growth continued during formation of new $\mathrm{CaCO}_{3}$ particles in the micelles (19). In supercritical chemical system, accelerated carbonation process was achieved by using ${ }_{\mathrm{sc}} \mathrm{CO}_{2}$ with high yield to produce $\mathrm{CaCO}_{3}$ particles in narrow particle size distribution (16). Among the nano- $\mathrm{CaCO}_{3}$ production processes, reactive precipitation was the most useful industrial technique because it has low cost and sustainable for a large scale process. However, aggregation is an important problem among the newly formed nano particles and new techniques are needed to overcome the detrimental drawbacks.

Nano particles are naturally unstable due to their unbalanced surface changes, which is generally related to their surface potential $(23,24)$. It is clear that the $\mathrm{CaCO}_{3}$ particles aggregate when the zeta potential is between $+30 \mathrm{mV}$ and $-30 \mathrm{mV}$ (25). A general consensus of about $-10 \mathrm{mV}$ of zeta potential value was reported for the $\mathrm{CaCO}_{3}$ (24). This value shows that the synthesized new $\mathrm{CaCO}_{3}$ clusters are naturally unstable. However, in one of our recent papers $(\underline{26})$, we reported that the zeta potential of $\mathrm{CaCO}_{3}$ particles are more than +30 $\mathrm{mV}$ in $\mathrm{Ca}(\mathrm{OH})_{2}$ solution and they are stable. We have proved that stable nano- $\mathrm{CaCO}_{3}$ particles could be produced in "hollow" shapes when $\mathrm{CO}_{2}$ was injected into the $\mathrm{Ca}(\mathrm{OH})_{2}$ solution as individual bubbles one after another (27). In this case, however, the $\mathrm{CaCO}_{3}$ crystallization rate was slower, the conversion took longer time, and the particle size was relatively larger with a particle size of about $450 \mathrm{~nm}$. In our subsequent paper, $\mathrm{CO}_{2}$ bubbles were injected into the $\mathrm{Ca}(\mathrm{OH})_{2}$ solution at much higher rates with $420 \mathrm{~mL} / \mathrm{min}$ and the newly produced particles were forced to be removed from the crystallization region into the
$\mathrm{Ca}(\mathrm{OH})_{2}$ solution as the stabilization region by a jet-flow (28). In such design, much smaller and "round" shaped nano- $\mathrm{CaCO}_{3}$ particles of about 300 $\mathrm{nm}$ were produced.

In the present study, a population of $\mathrm{CO}_{2}$ bubbles were injected into the $\mathrm{Ca}(\mathrm{OH})_{2}$ solution at a slower rate with $80 \mathrm{~mL} / \mathrm{min}$ and the effect of multiple bubbles next to each other on the formation of "hollow" nano- $\mathrm{CaCO}_{3}$ synthesis was investigated without a jet flow. It was found that the stirring rate was satisfactory to remove the newly synthesized nano- $\mathrm{CaCO}_{3}$ particles from the crystallization region into the stabilization region, where rice-like hollow nano- $\mathrm{CaCO}_{3}$ particles were produced. The chemical speciation reactions were also reviewed for the formation of stable nano$\mathrm{CaCO}_{3}$ particles with almost homogenous particle size distribution. It was concluded that hollow nano- $\mathrm{CaCO}_{3}$ particles can be produced by bubbling the $\mathrm{CO}_{2}$ into $\mathrm{Ca}(\mathrm{OH})_{2}$ solution with a concentration of $15 \mathrm{mM}$ without significant aggregation.

\section{MATERIALS AND METHODS}

Calcium hydroxide $\left(\mathrm{Ca}(\mathrm{OH})_{2}\right)$ was purchased from Merck, Germany, with a purity of about $96 \%$. The impurity contained $3 \%$ calcium carbonate $\left(\mathrm{CaCO}_{3}\right)$ and $1 \%$ other impurities such as $0.05 \%$ of $\mathrm{Na}, \mathrm{K}$, $\mathrm{Fe}, \mathrm{Sr} ; 0.5 \%$ of $\mathrm{Mg} ; 0.01 \%$ of $\mathrm{SO}_{4}{ }^{2-}$, and $0.005 \%$ of $\mathrm{Cl}^{-}$. Carbon dioxide $\left(\mathrm{CO}_{2}\right)$ gas was purchased from Carbogas, Turkey, and its purity was 99.99\%. Ultrapure water was obtained with a MilliQ (Millipore- Elix UV5/ Milli-Q) water purification system with a conductivity of 18.2 $\mathrm{M} \Omega . \mathrm{cm}$ at $25^{\circ} \mathrm{C}$.

\section{Stable Nano $\mathrm{CaCO}_{3}$ Synthesis}

The experimental set up designed to synthesize stable nano- $\mathrm{CaCO}_{3}$ particles in $\mathrm{Ca}(\mathrm{OH})_{2}$ solution (26) was shown in Figure 1. Different configurations in the experimental set up was also used in the synthesis of rice-like hollow nano$\mathrm{CaCO}_{3}$ particles with a single bubble injection (27) and round shape nano- $\mathrm{CaCO}_{3}$ particles with a jet flow (28). Briefly, the experimental set up consisted of a coil pipe containing small openings submerged in the $\mathrm{Ca}(\mathrm{OH})_{2}$ solution at the upper corner of the tank. Therefore, two "crystallization" and "stabilization" regions were created. The diameter of the holes on the coil was about $2 \mathrm{~mm}$ for the injection of a population of $\mathrm{CO}_{2}$ bubbles. 15 $\mathrm{mM}$ of $\mathrm{Ca}(\mathrm{OH})_{2}$ solution was prepared in ultrapure water to a final volume of 7 liters. Dissolution of $\mathrm{CO}_{2}$ from the atmosphere was measured and found negligible. The mechanical stirring rate was set to $800 \mathrm{rpm}$ to make a homogeneous mixing in the tank containing $\mathrm{Ca}(\mathrm{OH})_{2}$ solution and later the $\mathrm{CaCO}_{3}$ slurry. The total $\mathrm{CO}_{2}$ flow rate was 80 $\mathrm{mL} / \mathrm{min}$ so that the population of $\mathrm{CO}_{2}$ bubbles were used to test the effect of $\mathrm{CO}_{2}$ dissolution on the aggregation of newly synthesized $\mathrm{CaCO}_{3}$ 
crystallites and particle growth. $\mathrm{pH}$ and crystallization. conductivity values were monitored during the

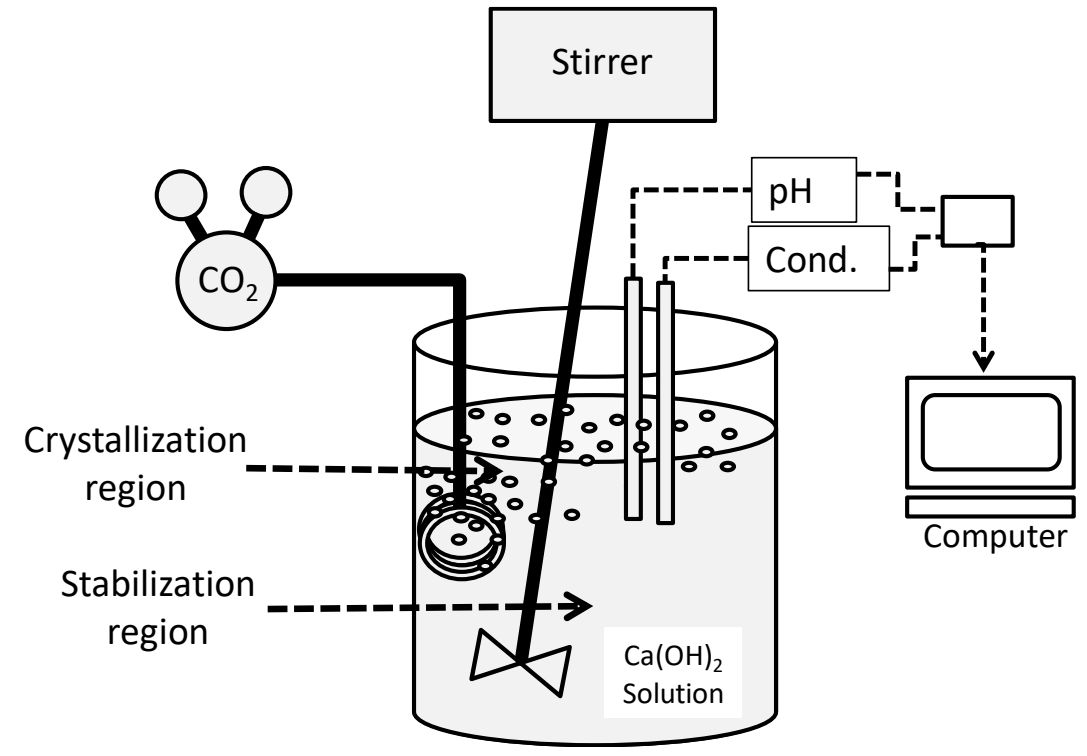

Figure 1: Experimental set up for stable nano- $\mathrm{CaCO}_{3}$ production.

\section{Sample Preparation and Characterization}

The average size, size distribution, and zeta potential values of the $\mathrm{CaCO}_{3}$ particles were measured by the dynamic light scattering (DLS) method using particle size analyzer (Malvern nano ZS model). Size distribution was obtained from 1 $\mathrm{mL}$ of sample withdrawn from the solution into a UV cuvette and measured by DLS. Zeta potential values were also measured using another $1 \mathrm{~mL}$ of sample withdrawn from the solution into a zeta cell and estimated by the DLS. At certain time intervals, precipitates were obtained by centrifugation at $9000 \mathrm{rpm}$ for $20 \mathrm{~min}$. The particles were washed with acetone and dried at $103{ }^{\circ} \mathrm{C}$ overnight. The morphologies of the $\mathrm{CaCO}_{3}$ crystals were determined by the scanning electron microscope (SEM) (Philips XL 30 S FEG). The crystal structure was determined using the X-ray powder diffraction (XRD) measurements.

\section{RESULTS AND DISCUSSION}

Crystallization of calcium carbonate is widely studied in the literature because it is a model system for ionic crystallization. The $\mathrm{CaCO}_{3}$ particles formed in chemical method are generally in micron sizes and $\mathrm{CaCO}_{3}$ particles synthesized in carbonization method are generally in nano sizes, however, they became usually aggregated (29), 30). In order to synthesize nano sized $\mathrm{CaCO}_{3}$ particles with a narrow particle size distribution, mass transfer between reactants need to be controlled in a semi-batch bubble reactor. This type of reactor is mostly used in gas-liquid reactive crystallization processes in industry (14).
The micron-scale bubble generation also helps micro-mixing. Therefore, the bubble reactor provides to maintain perfect mixing and a rapid mass transfer between reactants in $\mathrm{Ca}(\mathrm{OH})_{2}-\mathrm{CO}_{2}-$ $\mathrm{H}_{2} \mathrm{O}-\mathrm{CaCO}_{3}$ multiphase carbonization system. The size of gas bubbles is the most important parameter for an effective mass transfer and reactive absorption. Decreasing the bubble size causes to increase the gas-liquid interfacial area and the residence time for the bubbles by decreasing the lifting force on bubbles. The $\mathrm{CO}_{2}$ dissolution at the bubble surface can be increased upon increasing the retention time of the $\mathrm{CO}_{2}$ bubbles in the solution (15).

The present method was designed to synthesize nano- $\mathrm{CaCO}_{3}$ particles at narrow size distribution in a bubble crystallizer-reactor. The stability of the particles was achieved by the excess $\mathrm{Ca}^{2+}$ ions in the $\mathrm{Ca}(\mathrm{OH})_{2}$ solution when the surfaces of particles are covered by the $\mathrm{Ca}^{2+}$ ions and positively charged (26). Figure 2 shows the measured $\mathrm{pH}$ and conductivity values during crystallization in the presence of the $\mathrm{CO}_{2}$ bubbles. The numbers indicated on the figure show the time at which samples were taken from the crystallization reactor for analysis. As shown in the figure, a sudden increase in $\mathrm{pH}$ and conductivity was realized when powdered $\mathrm{Ca}(\mathrm{OH})_{2}$ was added into the ultrapure water. This was the first step in $\mathrm{CaCO}_{3}$ crystallization for the dissolution of powder $\mathrm{Ca}(\mathrm{OH})_{2}$ in water. $\mathrm{Ca}(\mathrm{OH})_{2}$ was the source for $\mathrm{Ca}^{2+}, \mathrm{OH}^{-}$, and $\mathrm{Ca}(\mathrm{OH})^{+}$ions in solution according to the chemical speciation reactions as follows (24): 


$$
\begin{aligned}
& \mathrm{Ca}(\mathrm{OH})_{2(\mathrm{~s})} \rightleftarrows \mathrm{Ca}(\mathrm{OH})_{2(\mathrm{aq})} \\
& \mathrm{Ca}(\mathrm{OH})_{2(\mathrm{aq})} \rightleftarrows \mathrm{Ca}(\mathrm{OH})^{+}{ }_{(\mathrm{aq})}+\mathrm{OH}^{-}{ }_{(\mathrm{aq})} \\
& \mathrm{Ca}(\mathrm{OH})^{+}{ }_{(\mathrm{aq})} \rightleftarrows \mathrm{Ca}^{2+}{ }_{(\mathrm{aq})}+\mathrm{OH}_{(\mathrm{aq})}^{-}
\end{aligned}
$$

Reactions (1) to (3) produce a homogeneous solution when the $\mathrm{Ca}(\mathrm{OH})_{2}$ concentration is less than its solubility limit of $18 \mathrm{mM}$ (26). However, when the $\mathrm{Ca}(\mathrm{OH})_{2}$ concentration is higher than its solubility limit, part of the powdery $\mathrm{Ca}(\mathrm{OH})_{2}$ exists in the solution in solid form and the solution becomes a slurry. In this case, the dissolution from the powder $\mathrm{Ca}(\mathrm{OH})_{2}$ occurs with a surface diffusion limited process (31).

$$
\begin{aligned}
& \mathrm{Ca}(\mathrm{OH})_{2} \longrightarrow \mathrm{Ca}^{2+}+2 \mathrm{OH}^{-}{ }_{\text {(surface) }} \\
& \mathrm{Ca}^{2+}+2 \mathrm{OH}_{\text {(surface) }} \longrightarrow \mathrm{Ca}^{2+}+2 \mathrm{OH}_{\text {(bulk solution) }}^{-}
\end{aligned}
$$

As shown in the figure, the $\mathrm{Ca}(\mathrm{OH})_{2}$ dissolution took more than 20 minutes in water, where the powder $\mathrm{Ca}(\mathrm{OH})_{2}$ was fully dissolved and converted into $\mathrm{Ca}^{2+}, \mathrm{Ca}(\mathrm{OH})^{+}$, and $\mathrm{OH}^{-}$ions.

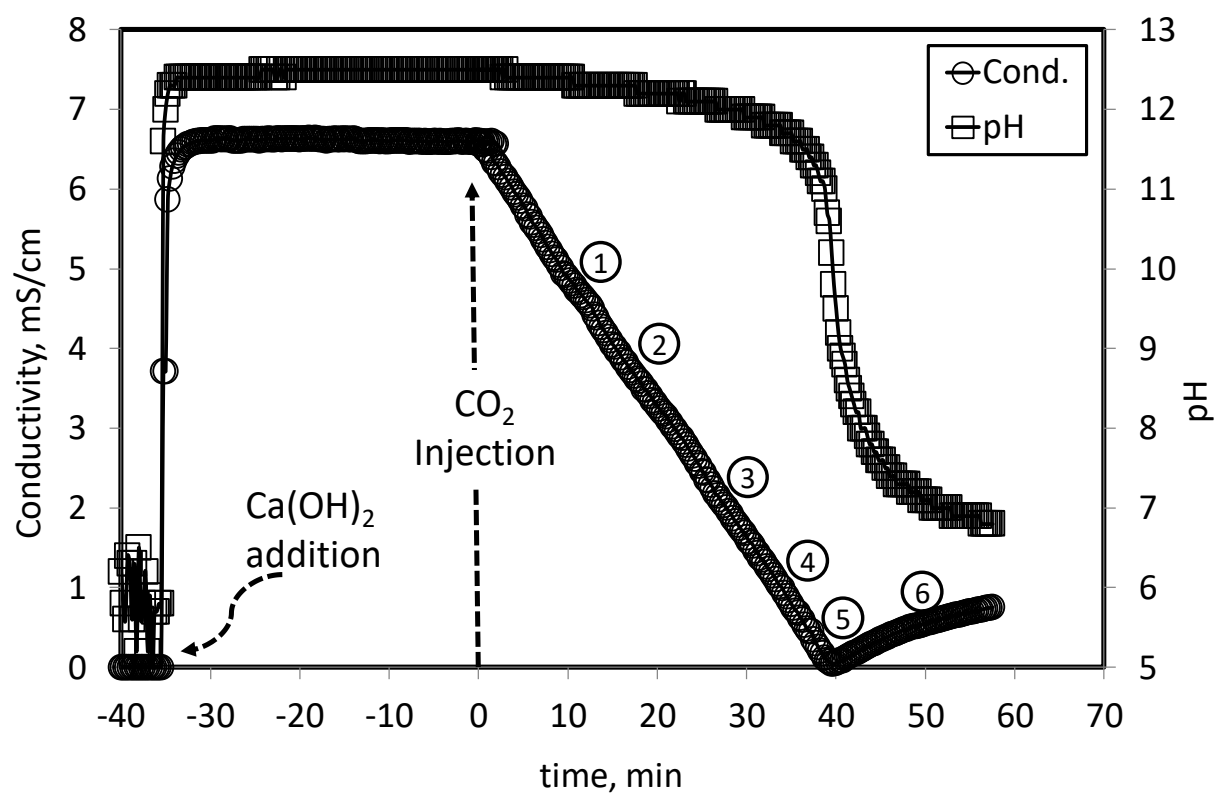

Figure 2: Changes in conductivity and pH during crystallization. Numbers indicate the time intervals where samples were taken.

The time was set to zero when the $\mathrm{CO}_{2}$ bubbles were injected into the $\mathrm{Ca}(\mathrm{OH})_{2}$ solution to initiate the $\mathrm{CaCO}_{3}$ crystallization. Therefore, the second step in $\mathrm{CaCO}_{3}$ crystallization was the dissolution of $\mathrm{CO}_{2}$ in $\mathrm{Ca}(\mathrm{OH})_{2}$ solution. The $\mathrm{CO}_{2}$ dissolution from the gas phase into the liquid phase is a complicated process. In the two-film theory, the

$$
\mathrm{CO}_{2(\mathrm{aq})}+\mathrm{OH}^{-} \rightleftarrows \mathrm{CO}_{3}{ }^{2-}+\mathrm{H}^{+}
$$

However, when pH was lower, other transformations were expected to occur at the gas-liquid interphase such as dissolution of $\mathrm{CO}_{2}$ in
$\mathrm{CO}_{2}$ first diffuses from the gas phase to the gasliquid interphase. Then, it dissolves at the gasliquid interphase. And finally, it diffuses through the liquid film into the solution (12). When $\mathrm{CO}_{2}$ was introduced into $\mathrm{Ca}(\mathrm{OH})_{2}$ solution at $\mathrm{pH} 12.6$, $\mathrm{CO}_{3}{ }^{2-}$ ions were expected to form preferentially (32).

aqueous phase (Eq. 5), hydration by water (Eq 6 ), followed by quick ionization into $\mathrm{HCO}_{3}{ }^{-}$and $\mathrm{H}^{+}$ ions (Eq. 7) (32).

$$
\mathrm{CO}_{2(\mathrm{~g})} \rightleftarrows \mathrm{CO}_{2(\mathrm{aq})}
$$




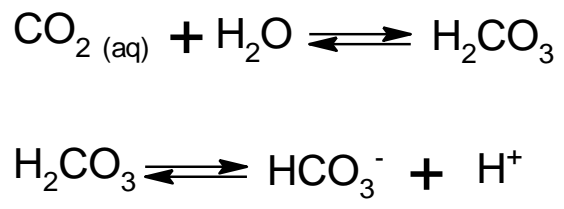

The dissolution of $\mathrm{CO}_{2}$ in an aqueous solution therefore decreases its $\mathrm{pH}$. It is known that the $\mathrm{pK}_{\mathrm{a}}$ of a carbonated water is about 6.4 at atmospheric pressure (26). This value becomes lower when pressure of $\mathrm{CO}_{2}$ is increased.

The third step in $\mathrm{CaCO}_{3}$ crystallization was the nucleation and crystalline growth. Newly synthesized nanocrystalline $\mathrm{CaCO}_{3}$ nuclei forms from the presence of $\mathrm{Ca}^{2+}, \mathrm{HCO}_{3}{ }^{-}$and $\mathrm{OH}^{-}$ions and other ionic species such as $\mathrm{CaHCO}_{3}{ }^{+}$and $\mathrm{CaOH}^{+}$ions. These latter ions could also participate in nano crystalline $\mathrm{CaCO}_{3}$ formation, which may initiate new nucleation sites or collide to form growing particles. Here, the solubility of $\mathrm{CaCO}_{3}$ is about $0.1 \mathrm{mM}(\underline{26})$ and all these species were eventually converted into the solid- $\mathrm{CaCO}_{3}$ particles.

$$
\begin{gathered}
\mathrm{Ca}^{2+}+\mathrm{HCO}_{3}^{-} \rightleftarrows \mathrm{CaHCO}_{3}^{+} \\
\mathrm{CaHCO}_{3}^{+} \rightleftarrows \mathrm{CaCO}_{3(\mathrm{aq})}+\mathrm{H}^{+} \\
\mathrm{Ca}^{2+}+\mathrm{CO}_{3}^{2-} \rightleftarrows \mathrm{CaCO}_{3}
\end{gathered}
$$

As shown in the figure, at the initial stage of crystallization, the $\mathrm{pH}$ and conductivity were higher. A pH value of 11.0 or higher is important for the calcite formation in the solution. When the $\mathrm{pH}$ is lower than 11.0 , other $\mathrm{CaCO}_{3}$ polymorphs such as aragonite, vatarite, and its different hydrated species would form during crystallization (33-37). The conductivity started to decrease almost linearly when $\mathrm{CO}_{2}$ bubbles were injected into the $\mathrm{Ca}(\mathrm{OH})_{2}$ solution. In the subsequent stages, the decrease in $\mathrm{pH}$ was relatively small. The conductivity was related to the $\mathrm{Ca}^{2+}$ ion concentration (26). A decrease in conductivity clearly indicated that the $\mathrm{Ca}^{2+}$ ions were consumed in the $\mathrm{Ca}(\mathrm{OH})_{2}$ solution to produce $\mathrm{CaCO}_{3}$ particles. The near zero conductivity value indicated the consumption of all $\mathrm{Ca}^{2+}$ ions in solution. At this late stage, an abrupt decrease in

$\mathrm{pH}$ was observed to about 7.0 due to a dissolving of an excess amount of $\mathrm{CO}_{2}$. In this case, an increase in $\mathrm{H}^{+}$and $\mathrm{HCO}_{3}{ }^{-}$ion concentrations results in a decrease in $\mathrm{pH}$ in the slurry. The low $\mathrm{pHs}$ cause the dissolution of some of $\mathrm{CaCO}_{3}$ particles releasing $\mathrm{Ca}^{2+}$ ions back into the slurry. Thus, the released $\mathrm{Ca}^{2+}$ ions and its new complexes with $\mathrm{OH}^{-}$and $\mathrm{HCO}_{3}{ }^{-}$ions to form $\mathrm{CaOH}^{+}$ and $\mathrm{CaHCO}_{3}{ }^{+}$species, respectively, increased the conductivity back again at the end of the crystallization as shown in the figure.

It is important to measure the $\mathrm{CO}_{2}$ diffusion rate or the $\mathrm{CaCO}_{3}$ crystallization rate during $\mathrm{CaCO}_{3}$ crystallization. We have shown that the conductivity is related to the $\mathrm{Ca}(\mathrm{OH})_{2}$ concentration up to its solubility limit of $18 \mathrm{mM}$ $(\underline{26})$.

$$
\text { Conductivity }=0.4268\left[\mathrm{Ca}(\mathrm{OH})_{2}\right]
$$

Here, the conductivity is in $\mathrm{mS} / \mathrm{cm}$ and $\left[\mathrm{Ca}(\mathrm{OH})_{2}\right]$ concentration is in $\mathrm{mM}$. Such relationship agreed very well with Burns et al. (38). Therefore, the $\left[\mathrm{Ca}^{2+}\right]$ ion concentration was estimated form the conductivity change during crystallization. The $\left[\mathrm{OH}^{-}\right]$ion concentration was calculated from Eq. (12), assuming that the $\mathrm{OH}^{-}$ions activity, $\mathrm{aOH}_{-}$, is about 1.0 .

$$
\left[O H^{-}\right]=10^{(-(14-p H))}
$$

The overall reaction for the crystallization of $\mathrm{CaCO}_{3}$ is given in Eq. 13, for which the $\mathrm{CaCO}_{3}$ crystallization rate will be equal to the $\mathrm{Ca}(\mathrm{OH})_{2}$

consumption rate as well as the $\mathrm{CO}_{2}$ consumption rate.

$$
\mathrm{Ca}(\mathrm{OH})_{2}+\mathrm{CO}_{2} \longrightarrow \mathrm{CaCO}_{3}+\mathrm{H}_{2} \mathrm{O}
$$


Therefore, the $\mathrm{CO}_{2}$ injection rate, the $\mathrm{Ca}(\mathrm{OH})_{2}$ consumption rate, and $\mathrm{CaCO}_{3}$ crystallization rate

Equations (11) and (12) respectively show the calculated $\left[\mathrm{Ca}^{2+}\right]$ and $\left[\mathrm{OH}^{-}\right]$ion concentrations and the results were plotted in Figure 3a. As shown in the figure, $\mathrm{Ca}^{2+}$ and $\mathrm{OH}^{-}$ion concentrations of 15 $\mathrm{mM}$ and $30 \mathrm{mM}$ were obtained, respectively, when $15 \mathrm{mM}$ of $\mathrm{Ca}(\mathrm{OH})_{2}$ was dissolved. As seen in the figure, $\mathrm{Ca}^{2+}$ and $\mathrm{OH}^{-}$ion concentrations both started to decline as the $\mathrm{CO}_{2}$ bubbles were introduced into the solution. Figure $3 \mathrm{~b}$ shows the consumption rates for the $\mathrm{Ca}^{2+}$ and $\mathrm{OH}^{-}$ions calculated from the slopes of the $\mathrm{Ca}^{2+}$ and $\mathrm{OH}^{-}$ion concentration curves in Figure 3a, respectively. As shown in the figure, the consumption rates for $\mathrm{Ca}^{2+}$ and $\mathrm{OH}^{-}$were estimated to be about 0.4 $\pm 0.07 \mathrm{mM} / \mathrm{min}$ and $0.8 \pm 0.2 \mathrm{mM} / \mathrm{min}$, respectively. Here, the $\mathrm{CO}_{2}$ consumption rate was calculated in 7 liter of $\mathrm{Ca}(\mathrm{OH})_{2}$ solution to be can be estimated from the conductivity measurements for the experiments.

about $0.047 \pm 0.012 \mathrm{mmoles} / \mathrm{s}$, which agree very well with the literature $(\underline{39}, \underline{40})$.

The experimental method can also be used in the estimation of $\mathrm{CO}_{2}$ dissolution rate and the enzymatic activity of carbonic anhydrase, an enzyme to catalyze the hydration of $\mathrm{CO}_{2}$ in aqueous media (41). Therefore, a new method was developed for the biocatalytic activity of carbonic anhydrase using $\mathrm{CO}_{2}-\mathrm{Ca}(\mathrm{OH})_{2}$ system (41). It was found that free-CA lost its activity in less than 6 mins at $\mathrm{pH} 12.5$ in $\mathrm{Ca}(\mathrm{OH})_{2}$ solution, however, its activity was retained when the CA was immobilized within polyurethane foam (41). Therefore, the biocatalytic activity of CA could be estimated at alkaline conditions in the aqueous solution of $\mathrm{Ca}(\mathrm{OH})_{2}(\underline{41})$.
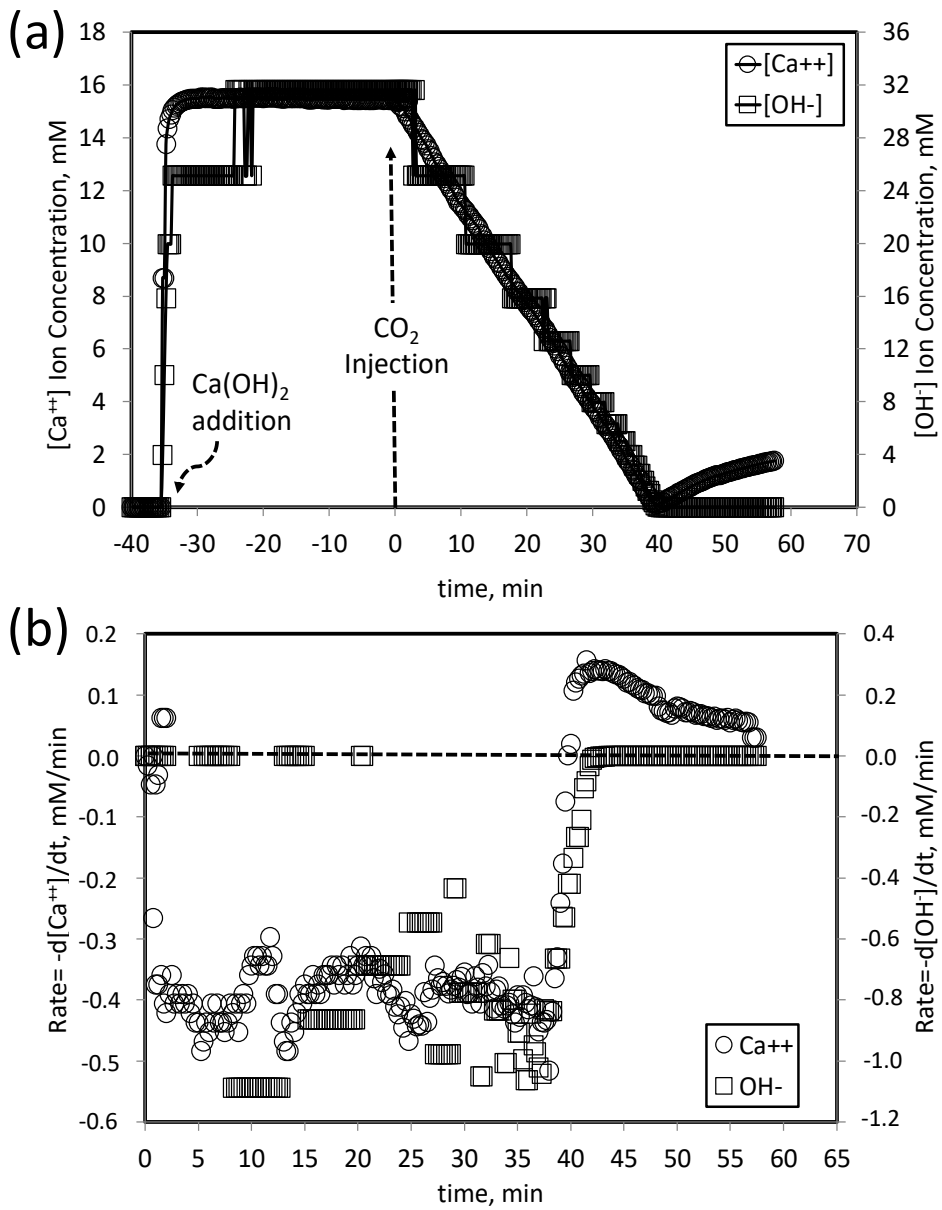

Figure 3. (a) Estimated $\mathrm{Ca}^{2+}$ and $\mathrm{OH}^{-}$concentrations in the stirred reactor during crystallization. (b) $\mathrm{Ca}^{2+}$ and $\mathrm{OH}^{-}$consumption rates calculated from the estimated concentrations.

Figure 4 shows the zeta potential values measured and the average particle sizes for the produced $\mathrm{CaCO}_{3}$ particles during crystallization. As Figure 4 shows, at the first stage of crystallization, the average size of particles was measured to be ca.
$300 \mathrm{~nm}$ and the estimated zeta potential value was about $+30 \mathrm{mV}$. The early stage particles were thought to be most probably charged nano $\mathrm{CaCO}_{3}$ clusters. As $\mathrm{CO}_{2}$ was injected into the solution, the average particle size was again about $300 \mathrm{~nm}$, 
and the zeta potential increased to about $+50 \mathrm{mV}$. The zeta potential is important for the surface charge of the particles. The positive zeta potential higher than $+30 \mathrm{mV}$ indicated that the $\mathrm{CaCO}_{3}$ particles obtained were in a stable form and little or no aggregation was expected to occur (25). As shown in the figure, the removal of particles from the crystallization region in the solution facilitated the formation of nano particles without aggregation and growth to larger particles. At the late stage, where the $\mathrm{Ca}^{2+}$ was consumed and $\mathrm{pH}$ decreased, the zeta potential value was shown to decrease to about $+24 \mathrm{mV}$ for which some aggregation expected to occur. Therefore, we observed that the average size of particles slightly increased. On the other hand, the measurement in an increase in $\mathrm{CaCO}_{3}$ particle size could be due to the increase in the population of the particles. When the number of particles increased in the solution, the scattered light to the detectors could be increased due to interactions of these particles in the slurry. Therefore, the figure shows that the increase in particle size towards the end of crystallization could be due to an artifact which can best be visualized from electron microscopic images.

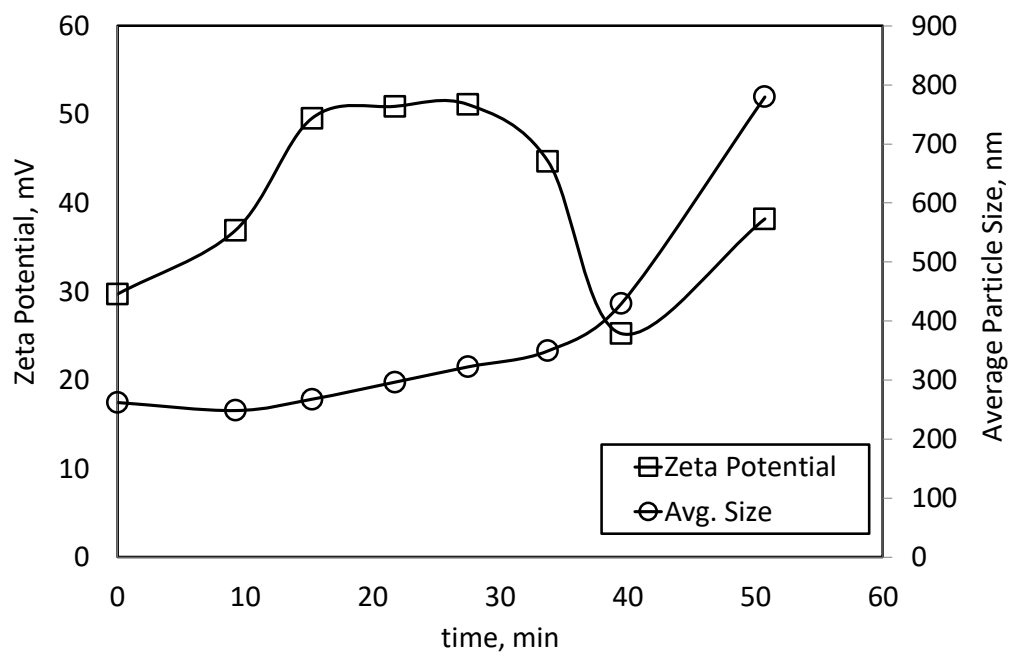

Figure 4. The zeta potential and average particle size for the particles that were obtained in the stirred reactor.

Figure 5 shows the scanning electron microscopy (SEM) images of the $\mathrm{CaCO}_{3}$ particles obtained at the indicated sampling time intervals of crystallization. The values for the conductivity, $\mathrm{pH}$ value, and zeta potential were also provided with the images. As shown in the images, rice-like and chunks of $\mathrm{CaCO}_{3}$ particles were seen before $\mathrm{CO}_{2}$ injection. The chunks of cubic $\mathrm{CaCO}_{3}$ residues were expected to come from the impurities in the $\mathrm{Ca}(\mathrm{OH})_{2}$ powder. The rice-like particles occurred at lower $\mathrm{CO}_{2}$ dissolution rates. Or, these rice-like $\mathrm{CaCO}_{3}$ particles did form initially due to a dissolution-recrystallization mechanism with $\mathrm{CaCO}_{3}$ particles that are present in the solution as the impurity as defined in the materials section ( $\underline{4}$, 42-44). When the $\mathrm{CO}_{2}$ bubbles were introduced in the solution, rice-like nano $\mathrm{CaCO}_{3}$ particles formed with an average particle size of about $220 \mathrm{~nm}$. Growing the primary $\mathrm{CaCO}_{3}$ crystals alongside indicating that the edges of the particles are the most energetic sites. Therefore, the $\mathrm{CaCO}_{3}$ particles grow much faster at their end-edges. No aggregation was seen due to the stabilization effect of $\mathrm{Ca}(\mathrm{OH})_{2}$ solution (26), where the zeta potential values were higher than $+30 \mathrm{mV}(25)$. During crystallization as $\mathrm{pH}$ of the solution started to decrease, some of the particles slightly dissolved at their edges and produced "hollow" $\mathrm{CaCO}_{3}$ particles. The growth rate and the dissolution rate were both higher at the edges of the $\mathrm{CaCO}_{3}$ particles. Some of the edges closed as a result of dissolution at low $\mathrm{pH}$ values and then recrystallization on the particles $(\underline{42}, \underline{44})$. The images indicate that negligible aggregations were seen due to their surface potentials indicated from higher zeta potential values. Any aggregation seen in the images, if any, would be probably the effect of drying on particles. The SEM images indicated that nano- $-\mathrm{CaCO}_{3}$ can be produced with almost homogenous size distribution. 


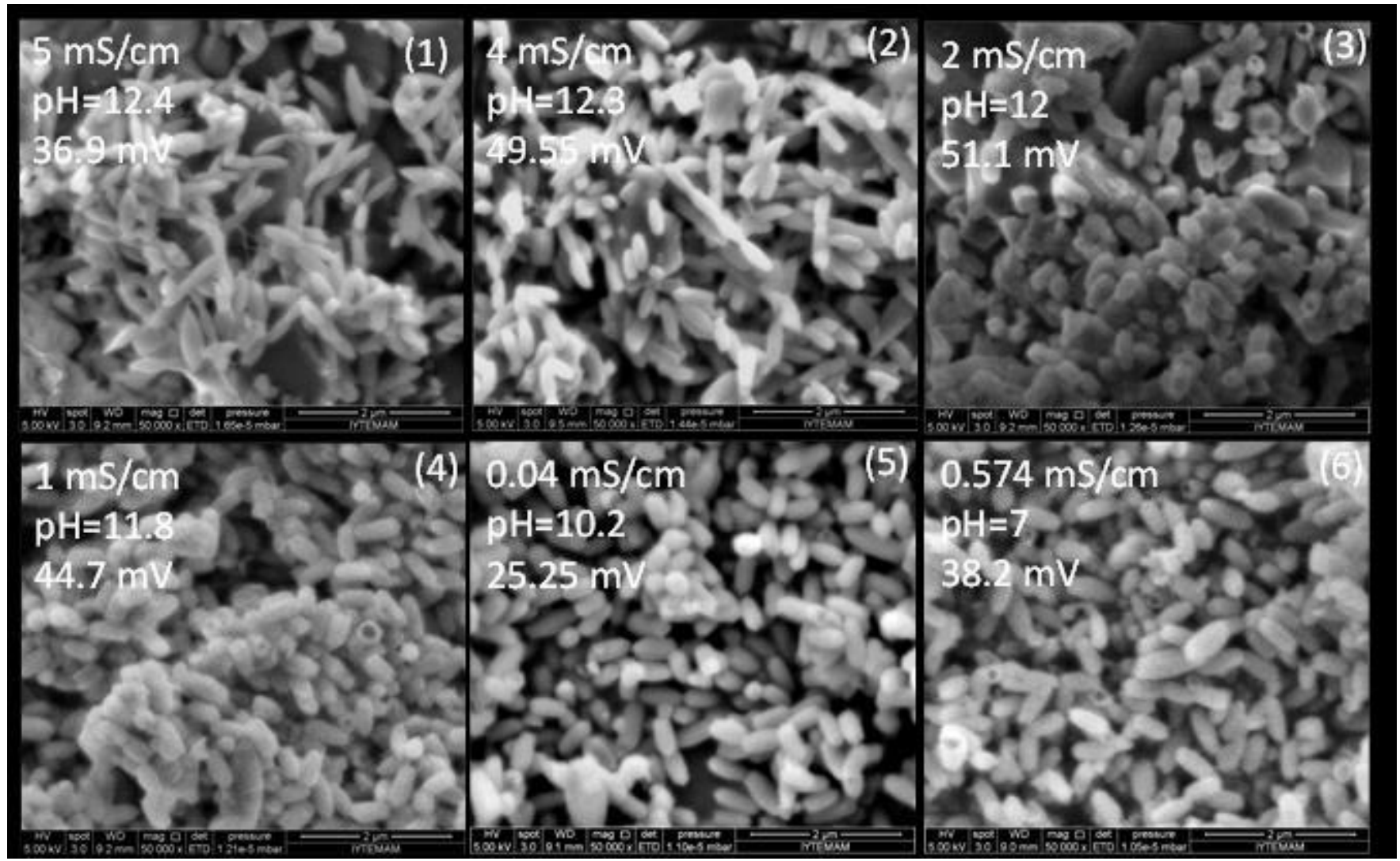

Figure 5. SEM images showing the progress of "hollow" nano $\mathrm{CaCO}_{3}$ particle production with homogenous size distribution.

XRD patterns for the produced $\mathrm{CaCO}_{3}$ particles indicated that these particles were all of calcite form as shown in Figure 6 . The $2 \theta$ value at $29.468^{\circ}$ showed the well-characterized calcite form of $\mathrm{CaCO}_{3}$. The Sheerer equation indicates that the crystallite species on the particles is about $40 \mathrm{~nm}$. Therefore, it was clear that when the particles were removed from the crystallization region and stabilized in the $\mathrm{Ca}(\mathrm{OH})_{2}$ solution, hollow nano calcite particles can be produced with a narrow size distribution.

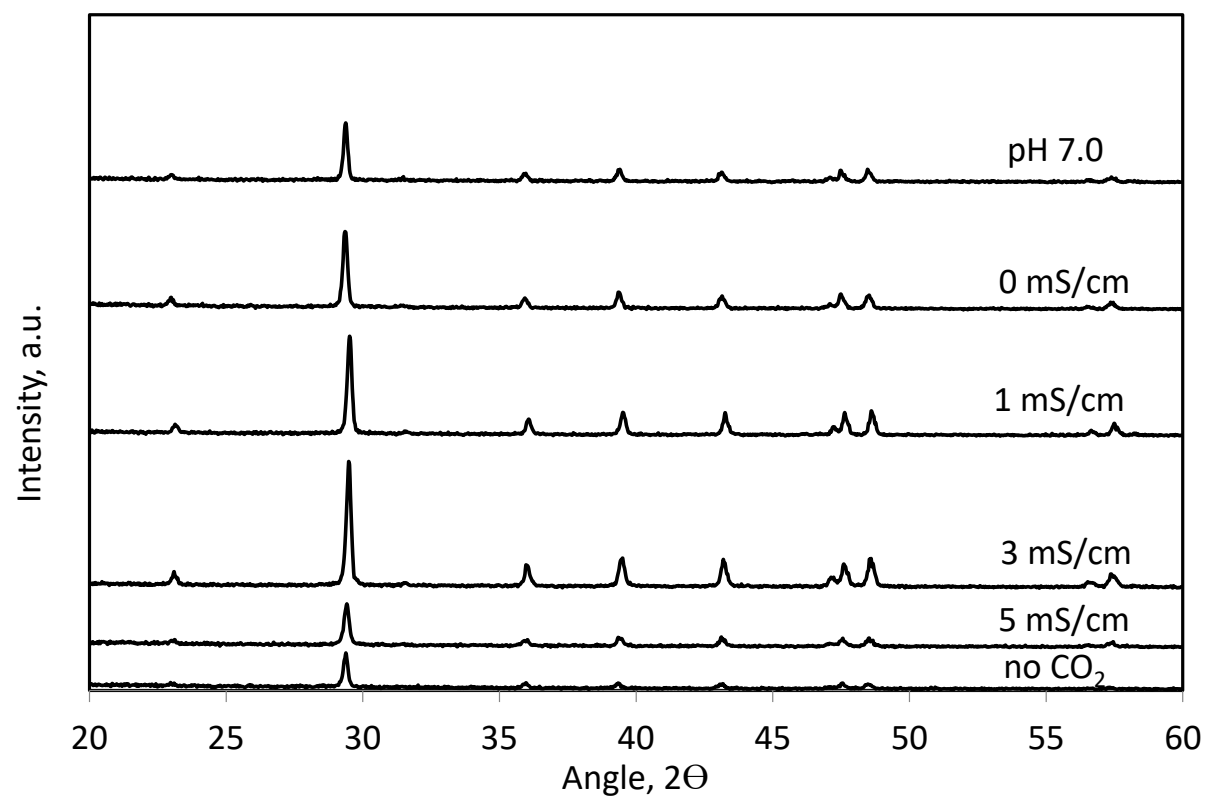

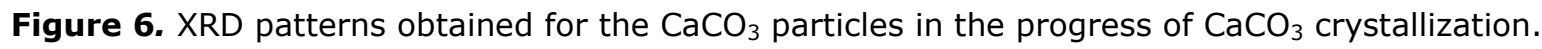




\section{CONCLUSIONS}

Calcium carbonate particles were synthesized with the carbonization method where a population of $\mathrm{CO}_{2}$ bubbles were introduced into the $\mathrm{Ca}(\mathrm{OH})_{2}$ solution. However, the $\mathrm{CO}_{2}$ bubbling was at the upper left corner of the solution so that the produced particles were separated from the crystallization region into the stabilization region by stirring. In this case, the zeta potential values for the particles were measured to be higher than $+30 \mathrm{mV}$ indicating that these particles were stable in $\mathrm{Ca}(\mathrm{OH})_{2}$ solution. To the end of crystallization, where $\mathrm{Ca}^{2+}$ ions were all consumed and $\mathrm{pH}$ decreased, some of the $\mathrm{CaCO}_{3}$ particles were seen to dissolve at their edges. The dissolution at the edges was faster for the rice-like $\mathrm{CaCO}_{3}$ particles. The dissolution from the edges resulted in an empty space in the $\mathrm{CaCO}_{3}$ particles. Therefore, "hollow" nano- $\mathrm{CaCO}_{3}$ particles were produced with homogenous size distribution without aggregation in the $\mathrm{Ca}(\mathrm{OH})_{2}$ solution. It was concluded that slower $\mathrm{CO}_{2}$ flow rates needed for the production of nano- $\mathrm{CaCO}_{3}$ particles at narrow size distribution.

\section{ACKNOWLEDGEMENTS}

The Scientific and Technological Research Council of Turkey (TUBITAK) is highly appreciated for the research grant with the project number of 110M104. The author also acknowledges Eda Ulkeryildiz for helping part of the experiments and Ekrem Ozdemir for valuable discussions.

\section{REFERENCES}

1. Fu SY, Feng XQ, Lauke B, Mai YW. Effects of particle size, particle/matrix interface adhesion and particle loading on mechanical properties of particulate-polymer composites. Compos Part BEng. 2008;39(6):933-61.

2. Bots $P$, Benning LG, Rodriguez-Blanco JD, Roncal-Herrero $T$, Shaw S. Mechanistic Insights into the Crystallization of Amorphous Calcium Carbonate (ACC). Cryst Growth Des. 2012;12(7):3806-14.

3. Lee KB, Park SB, Jang $\mathrm{YN}$, Lee SW. Morphological control of $\mathrm{CaCO} 3$ films with large area: Effect of additives and self-organization under atmospheric conditions. J Colloid Interf Sci. 2011;355(1):54-60.

4. Rieger J, Kellermeier M, Nicoleau L. Formation of Nanoparticles and Nanostructures-An Industrial Perspective on $\mathrm{CaCO} 3$, Cement, and Polymers. Angew Chem Int Edit. 2014;53(46):12380-96.

5. Sant'Anna SSE, de Souza DA, de Araujo DM, Carvalho CD, Yoshida MI. Physico-chemical
Analysis of Flexible Polyurethane Foams Containing Commercial Calcium Carbonate. Mater Res-Ibero-Am J. 2008;11(4):433-8.

6. Andreassen JP. Formation mechanism and morphology in precipitation of vaterite - nano aggregation or crystal growth? Journal of Crystal Growth. 2005;274(1-2):256-64.

7. Matahwa H, Ramiah V, Sanderson RD. Calcium carbonate crystallization in the presence of modified polysaccharides and linear polymeric additives. Journal of Crystal Growth. 2008;310(21):4561-9.

8. Jung WM, Kang SH, Kim KS, Kim WS, Choi CK. Precipitation of calcium carbonate particles by gas-liquid reaction: Morphology and size distribution of particles in Couette-Taylor and stirred tank reactors. Journal of Crystal Growth. 2010;312(22):3331-9.

9. Kakaraniya S, Gupta A, Mehra A. Reactive precipitation in gas-slurry systems: The $\mathrm{CO} 2 \mathrm{Ca}(\mathrm{OH})(2)-\mathrm{CaCO} 3$ system. Ind Eng Chem Res. 2007;46(10):3170-9.

10. Montes-Hernandez G, Renard F, Geoffroy N, Charlet L, Pironon J. Calcite precipitation from $\mathrm{CO} 2-\mathrm{H} 2 \mathrm{O}-\mathrm{Ca}(\mathrm{OH})(2)$ slurry under high pressure of CO2. Journal of Crystal Growth. 2007;308(1):22836.

11. Ukrainczyk M, Kontrec J, Babic-Ivancic V, Brecevic L, Kralj D. Experimental design approach to calcium carbonate precipitation in a semicontinuous process. Powder Technol. 2007;171(3):192-9.

12. Chen J-F, Wang $Y-H$, Guo F, Xin-Ming, Zheng C. <Synthesis of Nanoparticles with Novel Technology: High-Gravity Reactive Precipitation>. Industrial Engineering Chemical Research. 2000;39:948-54.

13. Sun $B-C$, Wang $X-M$, Chen J-M, Chu G-W, Chen J-F, Shao L. Synthesis of nano-CaCO3 by simultaneous absorption of $\mathrm{CO} 2$ and $\mathrm{NH} 3$ into $\mathrm{CaCl} 2$ solution in a rotating packed bed. Chemical Engineering Journal. 2011;168(2):731-6.

14. Varma S, Chen P-C, Unnikrishnan G. Gasliquid reactive crystallization for the synthesis of $\mathrm{CaCO} 3$ nanocrystals. Materials Chemistry and Physics. 2011;126(1-2):232-6.

15. Matsumoto $M$, Fukunaga $T$, Onoe $K$. Polymorph control of calcium carbonate by reactive crystallization using microbubble technique. Chemical Engineering Research and Design. 2010;88(12):1624-30. 
16. López-Periago AM, Pacciani R, García-González C, Vega LF, Domingo C. A breakthrough technique for the preparation of high-yield precipitated calcium carbonate. The Journal of Supercritical Fluids. 2010;52(3):298-305.

17. Sonawane SH, Shirsath SR, Khanna PK, Pawar $\mathrm{S}$, Mahajan CM, Paithankar V, et al. An innovative method for effective micro-mixing of $\mathrm{CO} 2$ gas during synthesis of nano-calcite crystal using sonochemical carbonization. Chemical Engineering Journal. 2008;143(1-3):308-13.

18. Plank J, Hoffmann H, Schölkopf J, Seidl W, Zeitler I, Zhang Z. Preparation and Characterization of a Calcium Carbonate Aerogel. Research Letters in Materials Science. $2009 ; 2009: 1-3$.

19. Tai CY, Chen C-k. Particle morphology, habit, and size control of using reverse microemulsion technique. Chemical Engineering Science. 2008;63(14):3632-42.

20. Kang SH, Hirasawa I, Kim WS, Choi CK. Morphological control of calcium carbonate crystallized in reverse micelle system with anionic surfactants SDS and AOT. J Colloid Interface Sci. $2005 ; 288(2): 496-502$.

21. Montes-Hernandez G, Renard F. Co-utilisation of alkaline solid waste and compressed-orsupercritical $\mathrm{CO} 2$ to produce calcite and calcite/Se0 red nanocomposite. The Journal of Supercritical Fluids. 2011;56(1):48-55.

22. Lin R-y, Zhang J-y, Bai Y-q. Mass transfer of reactive crystallization in synthesizing calcite nanocrystal. Chemical Engineering Science. 2006;61(21):7019-28.

23. Chibowski E, Holysz L, Wojcik W. Changes in Zeta-Potential and Surface Free-Energy of Calcium-Carbonate Due to Exposure to Radiofrequency Electric-Field. Colloid Surface A. 1994;92(1-2):79-85.

24. Chibowski E, Hotysz L, Szczes A. Time dependent changes in zeta potential of freshly precipitated calcium carbonate. Colloid Surface A. $2003 ; 222(1-3): 41-54$.

25. Kes M. Determination of the particle interactions - rheology- surface roughness relationshipmfor dental ceramics [M.S]. İzmir: İzmir Institute of Technology; 2007.

26. Kilic S, Toprak G, Ozdemir E. Stability of $\mathrm{CaCO} 3$ in $\mathrm{Ca}(\mathrm{OH})(2)$ solution. Int J Miner Process. 2016;147:1-9.
27. Ulkeryildiz E, Kilic S, Ozdemir E. Rice-like hollow nano-CaCO3 synthesis. Journal of Crystal Growth. 2016;450:174-80.

28. Ulkeryildiz E, Kilic S, Ozdemir E. Nano-CaCO3 synthesis by jet flow. Colloid Surface A. 2017;512:34-40.

29. Carmona JG, Morales JG, Rodriguez-Clemente R. Rhombohedral-scalenohedral calcite transition produced by adjusting the solution electrical conductivity in the system $\mathrm{Ca}(\mathrm{OH})(2)-\mathrm{CO} 2-\mathrm{H} 2 \mathrm{O}$. J Colloid Interf Sci. 2003;261(2):434-40.

30. Carmona JG, Morales JG, Sainz JF, Loste E, Clemente RR. The mechanism of precipitation of chain-like calcite. Journal of Crystal Growth. 2004;262(1-4):479-89.

31. Johannsen K, Rademacher S. Modelling the Kinetics of Calcium Hydroxide Dissolution in Water. Acta Hydrochimica Et Hydrobiologica. $1999 ; 27(2): 72-8$.

32. Ozdemir E. Biomimetic CO2 Sequestration: 1. Immobilization of Carbonic Anhydrase within Polyurethane Foam. Energ Fuel. 2009;23:572530.

33. $\mathrm{Xu}$ AW, Ma YR, Colfen H. Biomimetic mineralization. J Mater Chem. 2007;17(5):415-49.

34. Gunasekaran S, Anbalagan G. Spectroscopic study of phase transitions in natural calcite mineral. Spectrochim Acta A. 2008;69(4):124651.

35. Montes-Hernandez G, Fernández-Martínez A, Charlet L, Tisserand D, Renard F. Textural properties of synthetic nano-calcite produced by hydrothermal carbonation of calcium hydroxide. Journal of Crystal Growth. 2008;310(11):2946-53.

36. Carmona JG, Morales JG, Sainz JF, Clemente RR. Morphological characteristics and aggregation of calcite crystals obtained by bubbling $\mathrm{CO} 2$ through a $\mathrm{Ca}(\mathrm{OH}) 2$ suspension in the presence of additives. Powder Technol. 2003;130(1-3):30715.

37. Jung WM, Kang SH, Kim W-S, Choi CK. Particle morphology of calcium carbonate precipitated by gas-liquid reaction in a CouetteTaylor reactor. Chemical Engineering Science. 2000;55(4):733-47.

38. Burns JR, Jachuck JJ. Monitoring of $\mathrm{CaCO} 3$ production on a spinning disc reactor using conductivity measurements. Aiche J. 2005;51(5):1497-507. 
39. Lin RY, Zhang JY, Bai YQ. Mass transfer of reactive crystallization in synthesizing calcite nanocrystal. Chemical Engineering Science. 2006;61(21):7019-28.

40. Takemura F, Matsumoto Y. Dissolution rate of spherical carbon dioxide bubbles in strong alkaline solutions. Chemical Engineering Science. 2000;55(18):3907-17.

41. Molva M, Kilic S, Ozdemir E. Effect of carbonic anhydrase on $\mathrm{CaCO} 3$ crystallization in alkaline solution. Energ Fuel. 2016;30(12):10686-95.
42. Rodriguez-Blanco JD, Shaw S, Benning LG. The kinetics and mechanisms of amorphous calcium carbonate (ACC) crystallization to calcite, via vaterite. Nanoscale. 2011;3(1):265-71.

43. Rodriguez-Blanco JD, Shaw $S$, Bots $P$, RoncalHerrero $\mathrm{T}$, Benning LG. The role of $\mathrm{pH}$ and $\mathrm{Mg}$ on the stability and crystallization of amorphous calcium carbonate. J Alloy Compd. 2012;536:S477-S9.

44. Tai CY, Chen FB. Polymorphism of $\mathrm{CaCO} 3$ precipitated in a constant-composition environment. Aiche J. 1998;44(8):1790-8. 
Kilic S. JOTCSA. 2018; 5(2): 869-880. 